\title{
A rare cause of intercostal neuralgia: Ancient schwannoma of the chest wall
}

\author{
İnterkostal nevraljinin nadir bir nedeni: Göğüs duvarının ancient schwannoması
}

Mirac Aysen UNSAL, Bilal KELTEN, Altuğ KOSAR, Alpay ORKI

\begin{abstract}
Intercostal neuralgia is a rare condition that causes pain along the intercostal nerves. Neural tumors of the chest mostly arise from mediastinum and only less than $5-10 \%$ of primary tumors originate from intercostal nerves. These patients are usually asymptomatic. Herein, we report a 42-year-old male patient with severe intercostal neuralgia due to the schwannoma of the chest wall. The patient underwent surgical resection and his histopathological diagnosis was a very rare type of schwannoma: ancient schwannoma. Resecting the tumor relieved his pain.

Keywords: Ancient schwannoma, Schwannoma, Schwannoma of the chest wall

\section{ÖZ}

İnterkostal nevralji, interkostal sinir boyunca yayılan ağrı ile karakterize nadir bir durumdur. Torasik tümörler çoğunlukla mediasten kaynaklı olup, primer tümörlerin ancak \%5-10'dan azı interkostal sinirlerden orijin alır. $\mathrm{Bu}$ hastalar genellikle asemptomatik olurlar. Biz burada göğüs duvarı schwannoması nedeniyle ciddi interkostal ağrı ile başvurmuş 42 yaşında bir erkek hastayı sunduk. Cerrahi rezeksiyon sonrası schwannomanın nadir bir türü olan ancient schwannoma tanısı alan hasta, sonrasında ağrısız izlenmiştir.

Anahtar kelimeler: Ancient schwannoma, Schwannoma, Göğüs duvar1 schwannomas1
\end{abstract}

Mirac Aysen Unsal (西)

Department of Neurology, School of Medicine, Marmara University, Pendik, Istanbul, Turkey

e-mail: aysenunsal@yahoo.com

Bilal Kelten

Department of Neurosurgery, School of Medicine, Maltepe University, Maltepe, Istanbul, Turkey

Altug Kosar, Alpay Orki

Department Thoracic Surgery, School of Medicine, Maltepe University, Maltepe, Istanbul, Turkey

Submitted / Gönderilme: 23.10.2016

Accepted/Kabul: 20.12.2016

\section{Introduction}

Intercostal neuralgia is pain in the thoracic region emanating from intercostal nerves. Typical causes are thoracotomy, rib trauma, pregnancy and very rarely benign periosteal lipoma [1]. Schwannomas are benign, slow-growing neurogenic tumors originating from Schwann cells, mostly involving head, neck, flexor surfaces of extremities, posterior mediastinum and, retroperitoneum [2].

Chest wall is an unusual location for schwannomas and although they usually present with asymptomatic solitary mass, when symptomatic these tumors may cause radicular pain distributed along the course of affected nerve and produce compressive symptoms like cough and dyspnea.

Ancient schwannoma of the chest wall is a very infrequent medical situation and a very rare variant of schwannomas. It is an encapsulated tumor with benign nature which is usually located in the retroperitoneum [3]. Both sexes are equally affected in their third or fourth decades.

Computerized tomography (CT) and magnetic resonance imaging (MRI) scan of the thorax with contrast help to investigate the characteristics of the lesion. Complete surgical resection is the main treatment.

We report a rare case of ancient schwannoma of the chest wall presenting with intercostal neuralgia.

\section{Case Report}

A42-year-old man was evaluated with the severe pain of right posterolateral chest wall. The pain has become more severe in the last 2 weeks. He was examined by a neurologist and prescribed medication of pregabalin $300 \mathrm{mg}$ per day a week ago but the pain did not resolve completely. On admission, 
physical examination revealed a mobile, soft tissue mass bulging between ninth and tenth ribs. The mass was present for two years, but rapidly growing lately. The patient denied any history of trauma. A CT of thorax revealed an abnormal mass with a diameter of $3 \mathrm{~cm}$ (Figure.1A) in the right posterolateral chest wall. There was no connection with the lung parenchyma. Routine laboratory investigations and preoperative respiratory function tests were within normal limits. He had no other clinical history or lesions, suggesting neurofibromatosis.
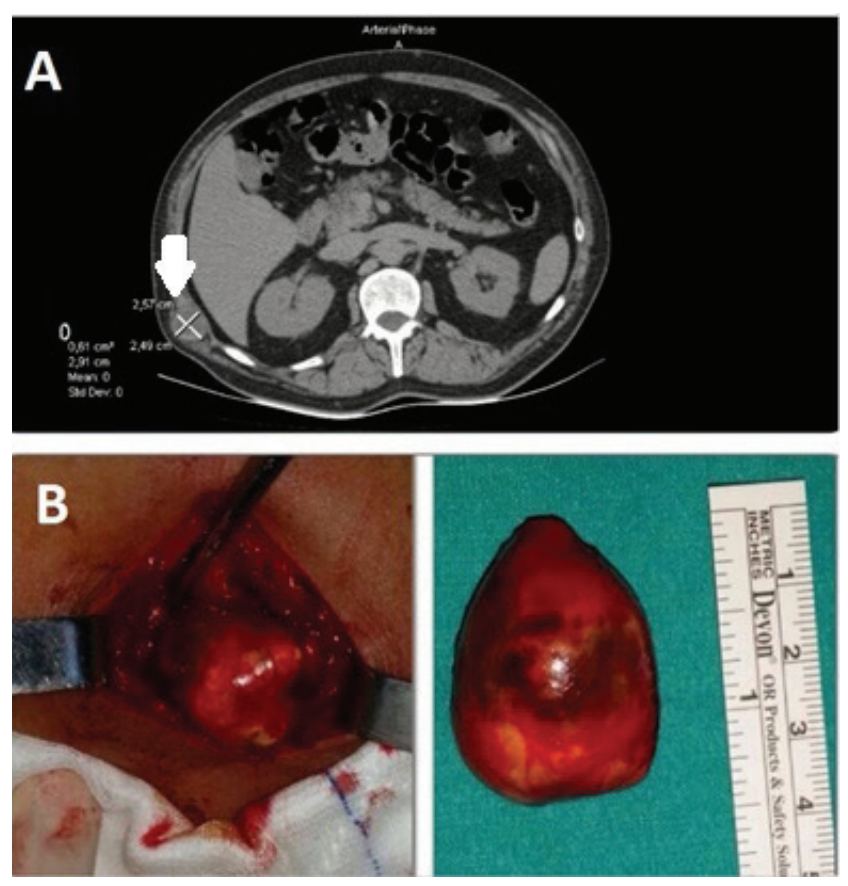

Figure 1. A. Computed tomography of the thorax revealed an abnormal mass with a diameter of $3 \mathrm{~cm}$ at the right posterolateral chest wall between ninth and tenth ribs. The arrow indicates the tumor. B. A well-encapsulated mass measuring $3.5 \times 3 \times 2.5 \mathrm{~cm}$ was easily dissected free from the surrounding tissues of the thoracic wall.

Surgery was performed with a $4 \mathrm{~cm}$ incision of the chest wall and muscles. A well encapsulated mass measuring $3.5 \times 3 \times 2.5 \mathrm{~cm}$ was easily dissected free from the surrounding tissues of the thoracic wall (Figure 1B). The surrounding fat tissue and muscles were relatively intact. The mass was wellshaped, grey-white colored encapsulated in cystic nature, containing pinkish-yellowish fluid. The cyst wall was made of uniform spindle cells. There were hyalinized vascular structures in myxoid stroma (Figure 2A). Microscopic study revealed both low and high cellularity together with wavy spindle cells. The tumor was totally degenerated with cystic formation and consisted with lipofuscin containing Schwann cell groups and lipid containing macrophages. (Figure 2B). Differentiated Schwann cells immunohistochemically expressed the S100 protein. These findings were consistent with a diagnosis of an ancient schwannoma originating from intercostal nerves with cystic nature.
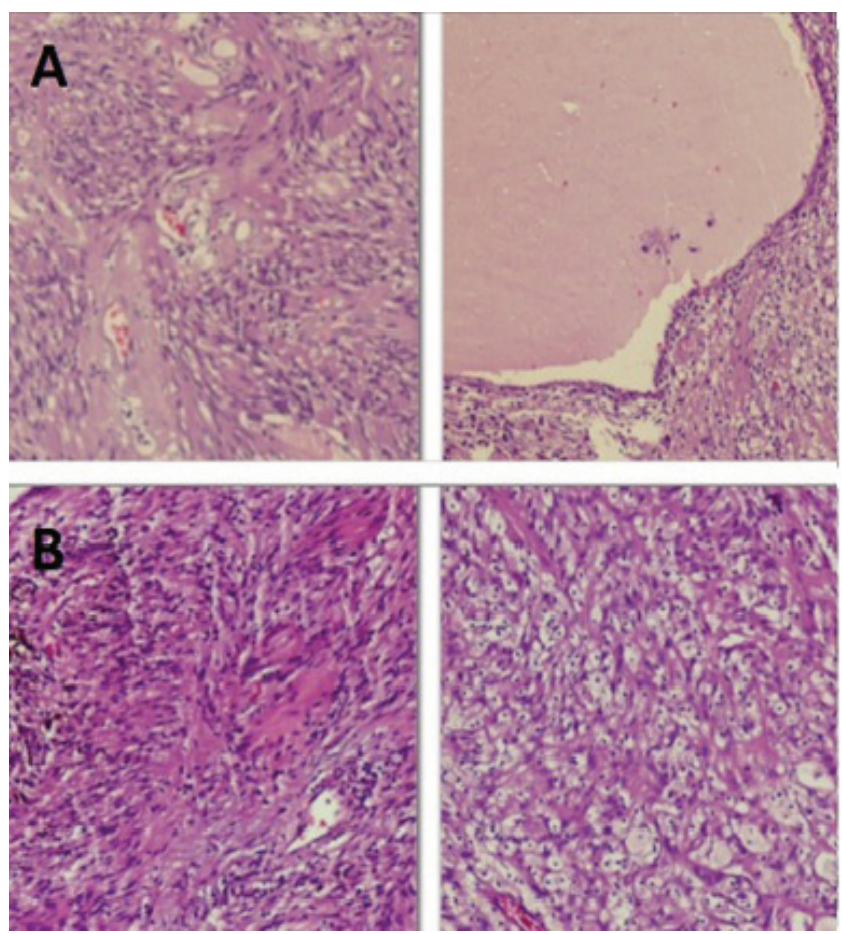

Figure 2.A. The cyst wall was made of uniform spindle cells. There were hyalinized vascular structures in myxoid stroma. B. The tumor was totally degenerated with cystic formation and consisted with lipofuscin containing Schwann cell groups and lipid containing macrophages.

As the patient's postoperative course was uneventful, he was discharged on the second day of operation. His dosage of pregabalin was tapered off slowly and he was completely pain free on the further visits.

\section{Discussion}

Tumors of the chest wall are mostly in metastatic nature. Primary chest wall tumors are very rare, representing approximately $5 \%$ of all thoracic neoplasms. Ancient schwannoma constitutes $0.8 \%$ of soft tissue tumors [2]. Less than $5-10 \%$ of all thoracic neural tumors originate from intercostal nerves [4-5].

Chest wall schwannomas are usually asymptomatic, slow growing, isolated, well-shaped benign lesions and are incidentally seen on imaging studies [6]. However, when they reach up to large dimensions, the compression may cause benign erosions and deformities of the ribs and vertebral bodies and may cause sensory changes distributed along the course of the affected nerve. Other presentations 
of intercostal schwannomas are Horner syndrome, hemothorax, dyspnea and subcutaneous tumors of the chest wall [7].

Our patient presented with a mass between ninth and tenth ribs, palpable under the chest wall, suggesting intercostal or metastatic masses. Although, the mass was present for years, it was rapidly growing in the last months and he was strongly complaining about neuralgia for two weeks.

Although both CT and MRI have excellent sensitivity for scanning schwannomas, appearing as spherical masses with clean lobular margins, CT is more readily available, less expensive and can be used as first imaging modality in majority of the cases. Our patient's lesion was clearly seen in CT. As the treatment of choice is usually radical surgical excision of the tumor by thoracoscopy or thoracotomy in order to confirm the preoperative diagnosis and to exclude the possibility of malignancy, our patient underwent an open surgery. His pathologic examination confirmed the initial diagnosis of a schwannoma. It was a rare, uncommon schwannoma variant, "ancient" schwannoma. The S-100 protein is a useful marker for Schwann cells and this immunological marker was also positive in our case [8].

Recurrence and malignant transformation of schwannomas are very rare [3]. Our patient is symptom free after one year of follow up.

\section{Conclusion}

We described a very rare case of an ancient schwannoma originating from an intercostal nerve on the chest wall. There are only a few cases reported in the available literature. The final diagnosis should be based on histopathological findings. Although their asymptomatic, slow growing, isolated, benign nature, our patient presented with a severe intercostal neuralgia. Complete resection leads to complete cure of this benign tumors.

\section{References}

1. Frontera WR, Silver JK, Rizzo TD, (editors). Intercostal neuralgia. Essensials of Physical Medicine and Rehabilitation. 3rd edition. Philadelphia: Elsevier, 2015:514.

2. Jain A, Suryakant Wani A. Dhar E, Sahu S, Iyengar Ambrish P. Ancient schwannoma of chest wall-A rare finding. IJHRS 2016;6:582-4.

3. Shubha PB, Permi HS, Shetty R, Shenoy J, Prasad K, Hegde P. Ancient schwannoma of the chest wall diagnosed by fine needle aspiration cytology - A rare case report. NUJHS 2012; $2: 27$.

4. Mcclenethan JH, Bloom RJ. Peripheral tumors of the intercostal nerves. Ann Thorac Surgery 2004;78:713-4. doi:10.1016/j.athoracsur.2003.09.022

5. Oosterwijk WM, Swierenga J. Neurogenic tumors with intrathoracic localization. Thorax 1968;23:374-84. doi: 10.1136/thx.23.4.374

6. Gul AA, Cobanoglu U, Kurt AK. An asympthomatic schwannoma originating from an intercostal nerve: A case report. Turkish J Thorac Cardiovasc Surg 2012;20:662-4. doi: 10.5606/tgkdc.dergisi.2012.132

7. Agrafiotis AC, Ikonomidis $\mathrm{P}$, Stamos N, Moraitis S. Thoracoscopic resection of an intercostal neurinoma. J Med Cases 2011;2:248-51. doi:10.4021/jmc243w

8. Schnitt SJ, Vogel H. Meningiomas. Diagnostic value of immunoperoxidase staining for epithelial membrane antigen. Am J Surg Pathol 1986;10:640-9. doi: 10.1097/00000478198609000-00006 